\title{
PEMBUATAN ALAT CUTTING HAND PRESS PADA KEMASAN MAKANAN RINGAN PRODUK UKM DI KOTA SERANG
}

\author{
Muryeti ${ }^{1}$, Novi Purnama Sari ${ }^{2}$, Wiwi Prastiwinarti ${ }^{3}$, Saeful $\mathrm{Imam}^{4}$, Rina Ningtyas ${ }^{5}$ \\ $1,2,3,4,5$ Politeknik Negeri Jakarta \\ Jln. Prof. Dr. G. A. Siwabessy, Kampus UI Depok \\ Email : yeti.tgp@gmail.com
}

\begin{abstract}
Abstrak
Kemasan menjadi faktor penting dalam meningkatkan nilai jual produk, selain itu kemasan berfungsi untuk melindungi produk, media promosi, menjadi identitas suatu produk, memperpanjang umur simpan produk, memudahkan dalam pendistribusian dan pemasaran produk, serta memenuhi kebutuhan dan kepuasan konsumen. Kota Serang merupakan salah satu target tempat wisata yang banyak dikunjungi wisatawan saat liburan. Hal ini menunjang perkembangan kuliner dan produk olahan hasil UKM di kota Serang untuk dijadikan produk oleh-oleh. Secara geografis, kota serang berada tidak jauh dari pesisir pantai utara sehingga banyak sumber daya hasil perikanan dan kelautan. Salah satu produk olahan hasil perikanan yang belum dikemas secara menarik adalah bakso goreng (makanan ringan yang berbahan dasar dari ikan). Bakso goreng sudah cukup dikenal oleh warga Serang, sebagai cemilan khas kota Serang. Namun aplikasi kemasan yang masih sangat minimalis menyebabkan produk ini tidak begitu dikenal oleh masyarakat luar daerah. Berdasarkan permasalahan kemasan tersebut, maka diperlukan suatu pengembangan alat kemasan efesien yang dapat diaplikasikan sehingga membantu UKM di daerah Serang untuk membuat kemasan secara mandiri. Program kerjanya mencakup perancangan dan pembuatan mesin produksi cetak alat cutting hand press dan, pelatihan serta pendampingan dalam penggunaan alat tersebut. Dengan adasnya alat cutting hand press sebagai mesin produksi cetak kemasan sekunder ini bisa membantu UKM Bakso Ikan Laksana meningkatkan kualitas dan nilai jual dari bakso goreng tersebut. Metode untuk melakukan program IPTEK bagi masyarakat ini adalah : tahap persiapan dengan melakukan survei ke daerah Serang dan membuat kerjasama dengan UKM setempat, tahap selanjutnya adalah merancang dan membuat alat cutting handpress sebagai mesin penunjang produksi kemasan yang sesuai dengan kebutuhan UKM dan ketersediaan bahan habis pakai yang bisa dibeli di kota Serang tersebut, setelah itu melakukan pendampingan pengoperasian alat cutting kemasan tersebut hingga UKM bisa melakukannya secara mandiri. Setelah dilakukan pelatihan dan pendampingan dalam pembuatan kemasan, UKM bakso Laksana, telah memiliki dan mampu membuat kemasan secara mandiri.
\end{abstract}

Kata kunci : cutting hand press, kemasan, UKM

\begin{abstract}
Packaging is an important factor in increasing the selling value of products. Other than that the packaging also works to protect products, promotional media, become product/brand identity, extend product shelf life, facilitate the distribution and marketing of products, and meet customer needs and satisfaction. Serang is one of the tourist attractions that are visited by many tourists during holiday. This supports the development of culinary and processed products that are produced by UKM/SMEs in Serang as souvenirs. Geographically, Serang is not far from the north coast and therefore has potential of fisheries and marine resources. One of processed fishery products, that has not been packaged attractively, are fried fish balls. Fried fish balls are quite popular as snacks in Serang. Because minimalism in application of packaging, this product is not well known by people outside city of Serang. Based on this problem, it is necessary to develop an efficient packaging tool that can be applied to help SMEs in Serang for making packaging independently. This work program includes the design and manufacture of hand press cutting molding machine, training and assistance in the use of this tool. Using of hand press cutting molding machine as secondary production machine is expected can help SME Bakso Ikan Laksana in improving the quality and sell value of fried fish balls.
\end{abstract}

Keywords: cutting handpress, packaging, UKM 


\section{PENDAHULUAN}

Besarnya tingkat antusias warga kota Serang dalam mengkonsumsi bakso goreng atau yang lebih dikenal dengan istilah "basreng" menyebabkan produk ini telah menjadi salah satu makanan khas asli olahan dari kota Serang. Salah satu UKM yang memproduksi basreng adalah UKM Bakso Ikan Laksana yang didirikan oleh Bapak Hasanudin sejak tahun 2003. UKM ini mengolah hasil perikanan menjadi makanan ringan baso ikan dengan merek "LAKSANA". Sejak awal berdiri UKM ini telah mengalami pasang surut hingga saat ini semakin berkembang melalui berbagai bantuan dari dinas pemerintah setempat. UKM ini terletak di daerah Sempu kota Serang dengan dibantu oleh 6 orang karyawan. Kapasitas produksi setiap harinya sekitar $100 \mathrm{~kg}-150 \mathrm{~kg}$, tergantung pada ketersediaan bahan baku ikan dari nelayan.

Produk bakso goreng yang dihasilkan mensuplai kebutuhan pasar makanan ringan di kota Serang. Produk yang didistribusikan masih dalam bentuk curah dengan menggunakan kemasan plastik sederhana dan belum mencantumkan merk produknya sendiri, kemudian produk bakso ikan laksana ini akan dikemas ulang oleh konsumen dengan menggunakan merek dagang mereka. UKM Bakso Ikan Laksana juga melayani permintaan konsumen langsung dalam kemasan platik tipis dengan bruto produk 100 gram seharga Rp. 4.000 tanpa menggunakan label kemasan. Selain itu UKM ini juga melayani permintaan khusus produk bakso ikan sebagai oleh-oleh Serang dengan menambahkan label kerta HVS tercetak yang masih sangat sederhana. Harga jual produk setelah diberi label menjadi Rp. 10.000. Namun pemahaman UKM Bakso Ikan Laksana terhadap pentingnya faktor kemasan dalam meningkatkan nilai suatu produk dan memberikan rasa aman konsumen terhadap kualitas produk melalui informasi yang ada di label kemasan masih sangat rendah. Padahal UKM Bakso Ikan Laksana telah memiliki sertifikat lengkap untuk produknya seperti PIRT dan Sertifikat Halal yang seharusnya dapat meningkatkan kepercayaan dan rasa aman konsumen.

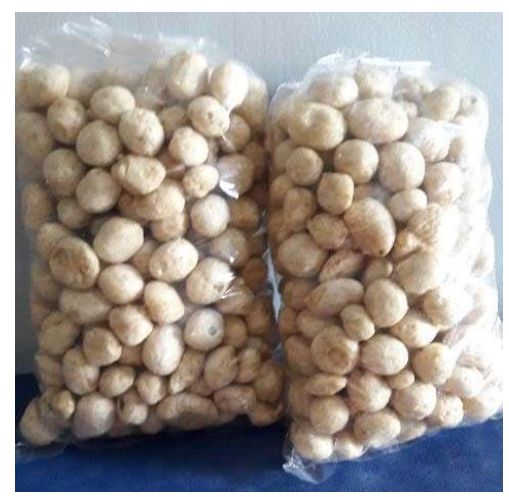

Gambar 1. Produk Bakso Goreng UKM

UKM Bakso Ikan Laksana memiliki peluang untuk diberikan bantuan berupa pembinaan maupun alat penunjang produksi kemasan secara manual yang mudah untuk digunakan oleh pihak UKM tersebut. Melalui bantuan ini diharapkan dapat meningkatkan value produk, kepuasan konsumen, dan tingkat penjualan produk di daerah lokal setempat, serta mampu memperluas area pemasaran dari produk bakso goreng agar produk khas ini lebih dikenal oleh masyarakat luas.

Permasalahan yang terkait produksi yang dihadapi oleh mitra yaitu kemasan produk bakso ikan laksana yang digunakan saat ini masih sangat sederhana. Hanya menggunakan plastik transparan sebagai material kemasan dan label kemasan yang direkatkan dengan steples. Kemasannya belum mencantumkan merk dagang UKM Laksana sendiri dan IPRT serta halal produk tersebut. Hal ini disebabkan pembuatan label kemasan akan menambah biaya produksi semakin meningkat. Selain itu pemasaran produk bakso goring tersebut terbatas pada wilayah Serang saja, dan proses produksi kemasan dilakukan secara manual, sehingga akan mempengaruhi kualitas dan ketahanan produk baso goreng didalamnya

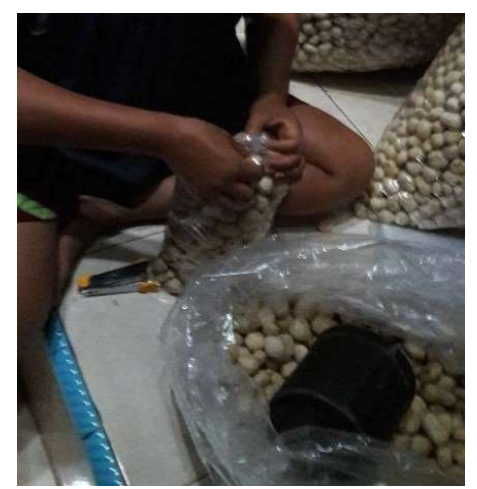

Gambar2. Proses pengemasan produk bakso goreng 
Permasalahan yang terkait dengan manajemen adalah manajemen usaha yang dilakukan masih sederhana, pemasaran yang masih terbatas, belum menggunakan teknologi informasi dalam pemasaran produknya. Permasalahan yang dihadapi oleh mitra sangat kompleks, maka permasalahan yang diprioritaskan dalam kegiatan ini adalah pembuatan desain dan kemasan produk bakso goring dengan menggunakan alat diecutting handpress manual.

\section{METODE PENGABDIAN}

Pelaksanaan kegiatan pangabdian masyarakat ini dilakukan dalam beberapa tahapan sebagai berikut:

1. Tahap persiapan dengan melakukan survey dan wawancara kebutuhan mitra UKM (mencakup jenis dan kompetisi produk UKM).

2. Tahap perancangan dan pembuatan alat cutting hand press kemasan sesuai dengan kebutuhan mitra. Alat cutting hand press merupakan alat dalam membuat label pada kemasan. Tahap pembuatan dengan melakukan proses manufaktur alat cutting hand press merupakan alat pemotong sticker sesuai dengan desain yang diinginkan. Selain untuk memotong, alat ini juga bisa digunakan untuk nometor, hotprint maupun pon. Penggunaan alat ini secara manual (Gambar 3). Visualisasi alat cutting hand press

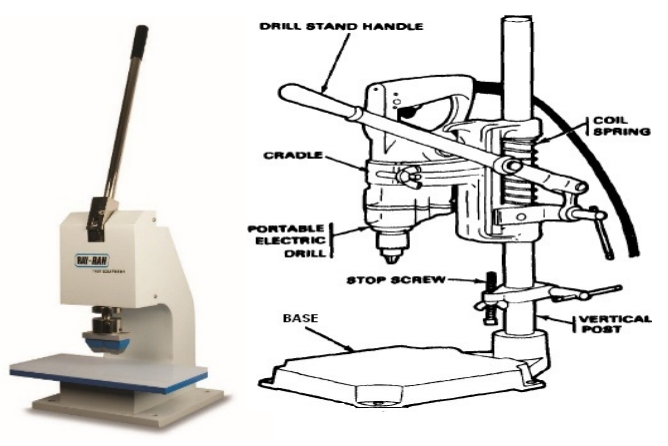

Gambar 3. Visualisasi Alat Cutting Handpress

Alat yang akan dibuat ini memiliki dimensi tergolong kecil dan mudah untuk digunakan. Komponen alat terdiri dari dua bagian pokok, yaitu meja mesin (yang merupakan bagian bawah alat) dan bagian mesin itu sendiri. Sistem kerja alat ini dibuat manual dan sangat sederhana. Kertas label/sticker di diletakkan di atas meja mesin (base), kemudian stoper lengan ayun (drill stand handle) digerakkan atau ditekan kearah bawah, dan kertas label telah terpotong dengan rapi. Kertas label yang dipotong dalam satu kali tekanan tidak dalam jumlah satuan, namun dapat dilakukan sampai ketebalan kertas $5 \mathrm{~cm}$.

3. Tahap pelatihan dan pendampingan pembuatan kemasan dan penggunaan alat cutting handpress

Setelah alat selesai dibuat, akan dilakukan pendampingan penggunaan alat, termasuk bila alat mengalami masalah kepada UKM bersangkutan dan serah terima alat die-cutting kepada pihak UKM. Kegiatan pendampingan berupa pelatihan dan tutorial prosedur penggunaan alat tersebut dengan sampel kemasan produk pada UKM dan perawatan alat dan penggantian variasi bentuk cutting pond untuk kemasan yang berbeda

Kegiatan pengabdian yang dilakukan dengan metode ceramah, diskusi, demonstrasi dan praktik langsung penggunaan alat. Metode ceramah digunakan dalam penyampaian dan pembekalan materi tentang pentingnya label kemasan suatu produk, Metode diskusi diguankan sebagai media komunikasi saat pelatihan berlangsung sehingga terjadi komunikasi dua arah antara pemateri dengan peserta. Metode demonstrasi dilakukan dalam memberikan contoh dan memeragakan cara penggunaan alat sehingga memudahkan peserta dalam memahami materi yang disampaikan. Metode praktik langsung dilakukan untuk mengaplikasikan mater yang terlah disampaikan dan operasional penggunaan alat dengan bimbingan trainer.

\section{HASIL DAN PEMBAHASAN}

Kegiatan pengabdian masyarakat" Pembuatan Alat Cutting Hand Press pada Kemasan Makanan Ringan Produk UKM 
di Kota Serang" dilakukan dengan beberapa tahapan utama yaitu dari pegumpulan informasi, perancangan dan persiapan pembuatan alat, pembuatan alat dan uji coba, pelaksanaan atau penyaluran alat, dan pelaporan serta evaluasi.

a. Tahap persiapan dan pengumpulan informasi

Proses pengumpulan informasi dilakukan untuk mencari permasalahan di lapangan yang dihadapi oleh mitra. Proses pengumpulan informasi dilakukan melalui survei langsung ke lokasi mitra di daerah Sempu Serang Banten. Informasi permasalahan UKM yang diperoleh adalah ketidaktersediaan media pengemasan yang memadai dan layak sesuai dengan standar teknik kemasan, yaitu penggunaan label kemasan sebagai media informasi tentang produk. Selain itu metode pengemasan dan material kemasan yang digunakan masih sangat sederhana tanpa mempertimbangkan keamanan makanan maupun umur simpan produk. Berdasarkan sumber permasalahan UKM tersebut, maka diperlukan alat Cutting Hand Press untuk mempermudah proses pemotongan label kemasan dan mengefektifkan waktu proses pemotongan. Beberapa data informasi lain yang dapat digunakan sebagai penunjang dalam proses pembuatan alat Cutting Hand Press adalah ukuran kemasan yang biasa digunakan oleh UKM untuk mengebam produk, serta beberapa informasi lain terkait informasi produk (brand, sertifikasi produk, komposisi) dan target pasar produk.

b. Perancangan dan persiapan pembuatan alat Pada tahap perancangan dan persiapan pembuatan alat, hal pertama yang dilakukan adalah menentukan dimensi/ukuran alat, bagian bagian alat, dan menggambar sketsa bentuk alat yang akan dibuat. Berdasarkan informasi ukuran kemasan yang biasa digunakan oleh mitra yakni plastik ukuran 1 kg dengan dimensi $15 \times 30 \mathrm{~cm}$ dan ukuran 2 $\mathrm{kg}$ dengan dimensi $20 \times 35 \mathrm{~cm}$, sehingga diperkirakan desain label yang akan dicetak tidak melebihi dari panjang $15 \mathrm{~cm}$. Hal ini akan menentukan luas bidang tempat pemasangan pisau potong yang akan direncanakan yaitu berukuran $(20 \times 20) \mathrm{cm}$. Bagian-bagian alat terdiri dari kaki sebagai tumpuan, meja (base) guna meletakan kertas yang akan dipotong, bidang pemasangan pisau potong, dan stoper lengan ayun (drill stand handle) guna memberikan gaya tekan saat proses pemotongan label.

Sistem penggunakan alat juga dirancang secara manual dan sangat sederhana dengan teknik tekan ke arah bawah stoper lengan ayun pada alat. Hal ini akan mempermudah pihak UKM dalam penggunaannya. Ketebalan tumpukan kertas yang dapat dipotong diatas meja (base) adalah tidak lebih dari $5 \mathrm{~cm}$ atau kurang lebih dapat memotong 100 lembar label kemasan dalam sekali proses potong. Material yag dibutuhkan untuk pembuatan alat cutting hand press adalah besi pejal, baut, plate pisau potong, per, karet bantalan pisau, cat, dan lain sebagainya.

Setelah dilakukan perancangan alat, langkah selanjutnya adalah trial model desain label yang akan diaplikasikan ke UKM. Proses trial desain label kemasan yang akan digunakan berukuran 15 x 4,5 cm, berbentuk elips, menggunakan 2 jenis material yaitu art cartoon dan kertas stiker. Untuk label yang menggunakan material art cartoon pengaplikasiannya pada kemasan diletakan di bagian atas kemasan, sedangkan untuk kertas stiker bisa dietakan di tengah kemasan. Langkah selanjutnya adalah menggambar sketsa bentuk alat yang akan dibuat. Gambar sketsa bentuk alat cutting hand press ditunjukan pada Gambar

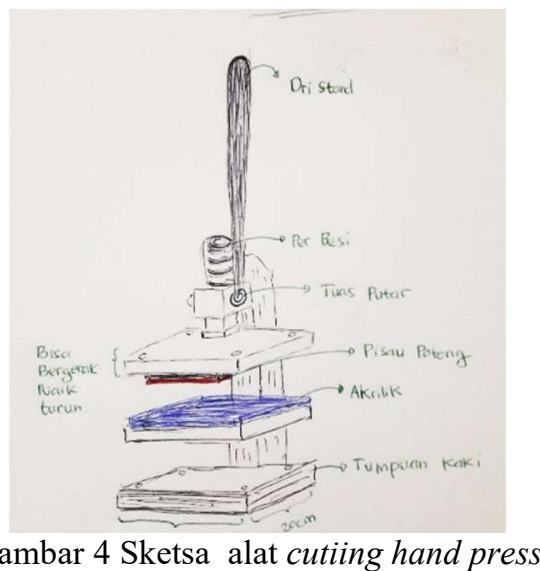

\section{b. Pembuatan Alat dan Uji Coba}

Proses pembuatan alat ini berlangsung selama 5 minggu bersamaan dengan proses desain label kemasan dan pembuatan plate cetak label kemasan. Setelah itu dilakukan uji coba kinerja alat cutting hand press. Berikut adalah gambar alat cutting hand press yang telah selesai dibuat dan desain label kemasan yang digunakan.

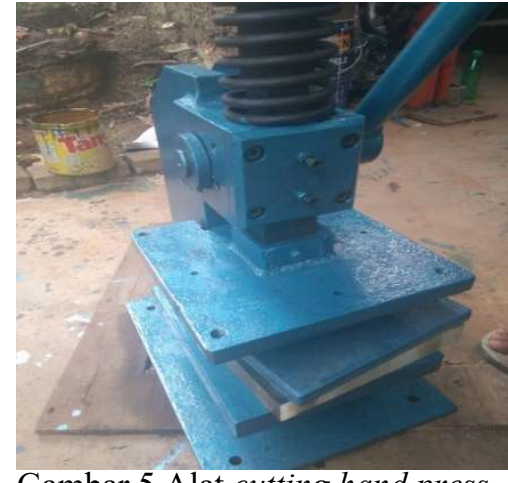

Gambar 5.Alat cutting hand press 


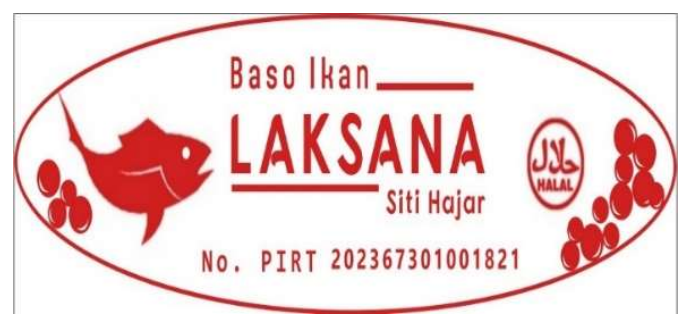

Gambar 6. Desain label kemasan yang digunakan

\section{c. Pelaksanaan Pelatihan dan Pendampingan Pembuatan Kemasan dan penggunaan alat diecutting}

Kegiatan penyaluran dan pendampingan penggunaan alat produksi dilaksanakan pada tanggal 13-14 Oktober 2017. Pelaksanaan kegiatan dilakukan dengan memberikan pelatihan dan materi mengenai label kemasan dan menyalurkan alat cutting hand press, memberikan pelatihan cara penggunaan alat, serta maintenance alat tersebut. Kegiatan ini dihadiri oleh 5 peserta yang berasal dari beberapa UKM lainnya termasuk UKM Laksana sebagai mitra yang berada di daerah Sempu, Kota Serang. Peserta diberi bimbingan dan pelatihan tentang sosialisasi pentingnya penggunaan label kemasan untuk produk UKM. Pelatihan ini diharapkan dapat meningkatkan pemahaman peserta UKM tentang pentingnya penggunaan label kemasan produk makanan sehingga sebuah label sangat memiliki peranan penting sebagai media pemberi informasi dan identitas suatu produk sangat penting. Pelatihan ini juga memberikan pengetahuan kepada peserta UKM bahwa suatu produk makanan yang baik harus minimal memiliki No PIRT, BPOM, dan Halal sebagai kelegalan suatu produk. Produk makanan yang tidak atau belum memiliki syarat kelegalan tersebut maka dapat memungkinkan terjadinya tindakan-tindakan yang tidak diinginkan seperti sabotase dan penipuan dari pihak lain yang tidak bertanggung jawab. Sehingga pemahaman para pelaku UKM terkait pentingnya penggunaan label kemasan adalah hal yang sangat penting.

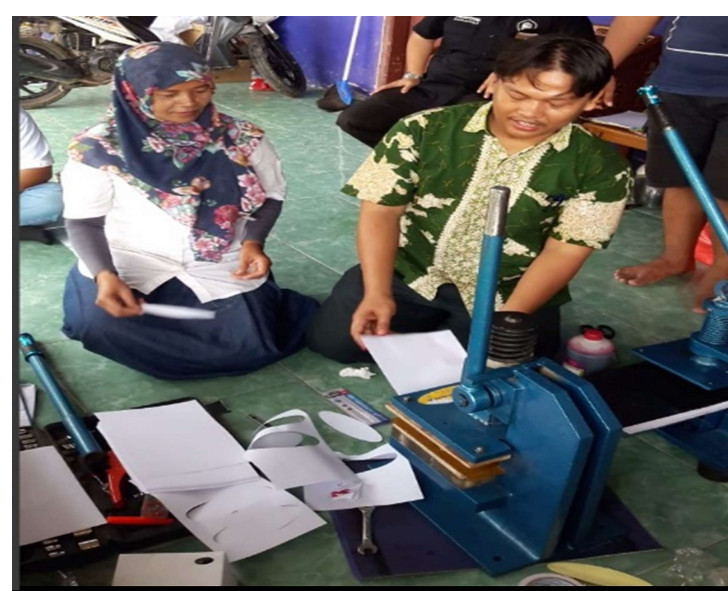

Gambar.7. pembekalan dan pembimbingan tentang label kemasan produk

Setelah itu dilanjutkan dengan pelatihan penggunakan alat pemotong (die-cutting) untuk membentuk pola kemasan produk yang praktis.

Alat pemotong (die cutting) yang digunakan untuk membuat kemasan produk bakso goreng dioperasionalkan secara manua dan mudah digunakan, sehingga sesuai dengan kebutuhan UKM. Apabila ingin membuat desain kemasan produk lainnya yang berbeda bentuk maupun ukurannya, tinggal mengganti pisau pond yang digunakan.

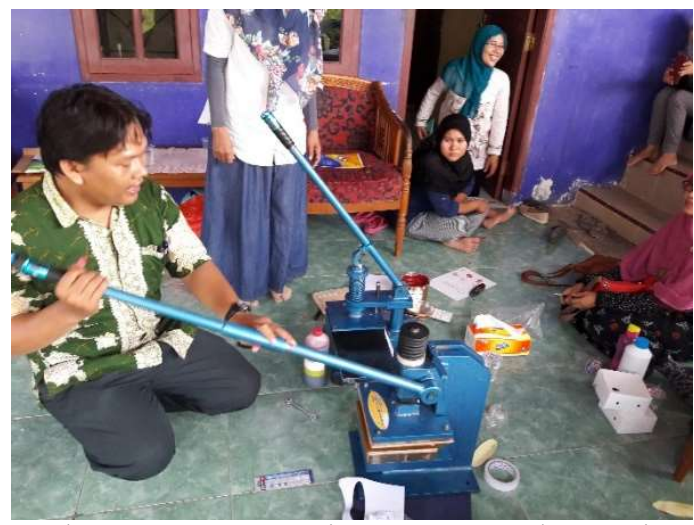

Gambar. 8. Demonstrasi penggunaan alat cutting

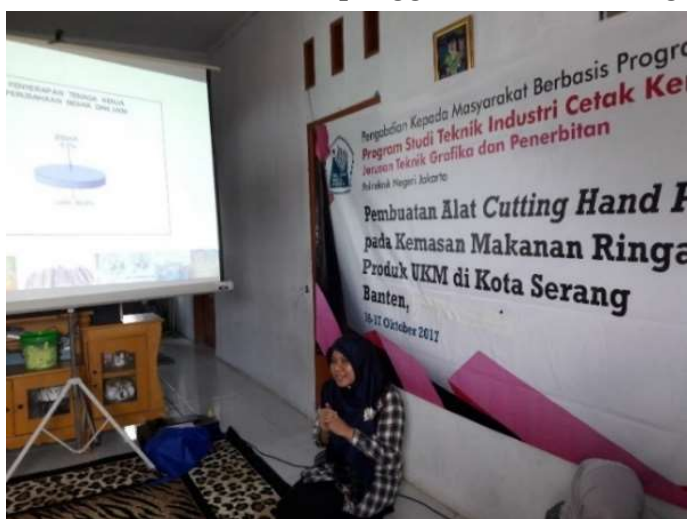

Gambar. 8. Pelatihan praktik penggunaan alat cutting handpress 


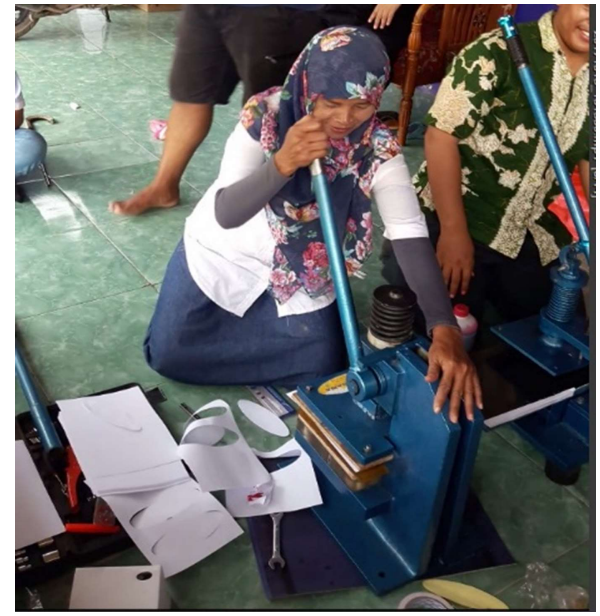

Gambar 9.Peserta praktek menggunaan Alat Cutting

Setelah dilakukan pelatihan prosedur penggunaan dan perawatan alat die-cutting, kemudian pihak Prodi TICK memberikan alat die cutting tersebut kepada pengelola UKM Laksana. Pihak Prodi TICK berharap dengan diberikan alat die cutting tersebut terdapat peningkatkan produktivitas dari segi waktu dan biaya produksi kemasan UKM Laksana dan , dapat memproduksi kemasan produk secara mandiri dan meminimalisir biaya produksi.

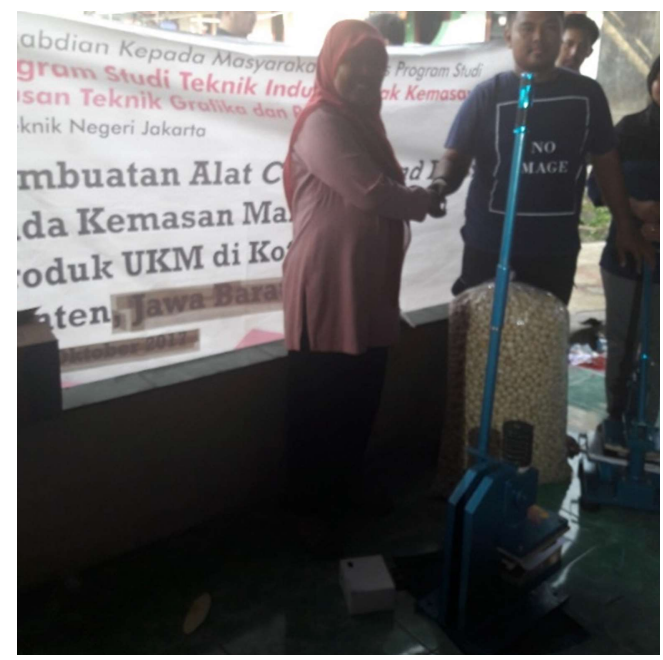

Gambar 10. Proses Serah Terima Alat Cutting oleh Kaprodi Teknologi Industri Cetak Kemasan PNJ

\section{KESIMPULAN}

1. Tersedianya alat pemotong (die-cutting) bentuk pola kemasan produk yang praktis dan hemat energi untuk mengemas produk kemasan makanan ringan produk UKM.

2. Alat die-cutting yang digunakan untuk mengemas makanan ringan dioperasikan secara manual dan sederhana sehingga tidak mengakibatkan kenaikan biaya produksi produk, dan dapat disesuaikan dengan desain kemasan berbagai produk.

3. UKM dapat memproduksi kemasan produk secara mandiri menggunakan alat die cutting. Diharapkan dengan adanya alat ini adalah adanya meningkatkan produktivitas dari segi waktu dan biaya produksi kemasan dengan menggunakan alat die-cutting sederhana.

\section{SARAN}

Diharapkan untuk kegiatan pengabdian masyarakat selanjutnya dapat dikembangkan mesin automatis die cutting yang mudah diterapkan di UKM.

Ucapan Terima Kasih

Penulis mengucapkan terima kasih kepada P3M PNJ yang telah memberi dan dukungan terhadap keberhasilan pengabdian ini. Terima kasih penulis ucapkan kepada UKM Serang yang telah menjalin kerjasama dalam kegiatan pengabdian ini.

\section{DAFTAR PUSTAKA}

\section{Dinas Perindustrian, Perdagangan dan Koperasi Kota Serang. 2010. Jumlah IKM Sate Bandeng di Kota: Serang Tahun 2011. Serang}

Kota Serang. 2010. Jumlah IKM Sate Bandeng di Kota Serang Tahun 2011. Serang : Dinas Perindustrian, Perdagangan dan Koperasi Kota Serang

Mendis, BSU. MT Medagedara . 2015. An improved design of a string hopper machine to suit the local requirements. dr.lib.sjp.ac.lk

Ngatindriatun, Hertiana I. 2011. Efisiensi Produksi Industri Kecil Batik Semarang : Pendekatan Fungsi Produksi Frontier Stokastik. Jurnal Manajemen 
